\title{
Imagem humana à semelhança de Deus Proposta de Antropologia Teológica
}

\author{
SOUZA, José Neivaldo de. \\ São Paulo: Paulinas, 2010.
}

Prof. Dr. Sérgio Corrado*

A presente publicação da Editora Paulinas enriquece a coleção Iniciação Teológica que busca contribuir para a formação de leigos e leigas que desejam entrar no universo teológico.

$\mathrm{O}$ autor, além de Doutorado em Teologia Fundamental pela Universidade Gregoriana de Roma, é Mestre em Psicologia Clínica e em Filosofia. Nesta obra, José Neivaldo de Souza demonstra sua reflexão filosófica e teológica sobre a condição humana à luz da fé: une sua pesquisa à docência e experiência de vida. O tema que direciona todo o trabalho é dado pelo próprio autor na Introdução:...."propomos uma reflexão

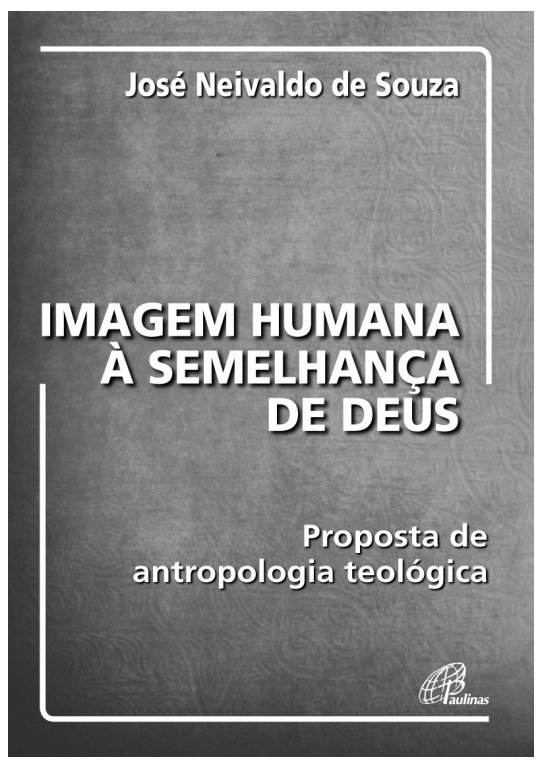
antropológica cujo objetivo é responder às perguntas sobre o ser humano a partir da fé ou refletir sobre a condição humana no plano de Deus: criação, queda e salvação". O objetivo é desenvolvido em cinco capítulos bem conectados e conduzem o leitor a um entendimento da condição humana, como reflexo de Deus.

No primeiro capítulo é feita a seguinte pergunta: qual é o lugar de ser humano no mundo? E a partir daí, o autor apresenta uma reflexão antropológica à luz da Bíblia, através da teologia e filosofia, colocando o ser

* Professor da Faculdade de Teologia PUCSP. Departamento de Prática. 
humano como cabeça da criação. E aí temos uma importante apresentação do conceito de cabeça, não apenas como um receptáculo de pensamentos, mas teologicamente a partir de 1Cor 11,3: "Quero que saibais o seguinte: a cabeça de todo homem é Cristo, mas a cabeça da mulher é o homem e a cabeça de Cristo é Deus". Na realidade, trata-se de um capítulo introdutório no qual se projeta a reflexão antropológica como importantíssima para se perceber o ser humano em ralação a Deus, a abertura do Criador ao homem e a convivência de ambos.

No capítulo seguinte, o autor busca em alguns Padres da Igreja o embasamento do seu projeto; por exemplo, a antropologia de Santo Irineu de Lyon sobre a criação humana; Clemente de Alexandria, Orígenes e Agostinho sobre a imagem e semelhança de Deus. Na realidade, trata-se de mostrar a criação, a queda e a redenção do ser humano na imagem do logos, Jesus Cristo. Avançando no tempo e no saber, pouco a pouco, através do Mestre Eckart, filósofo e místico, o autor trata da dimensão espiritual do ser humano diante do problema de Deus: como equacionar a grandeza do Deus que cria com a miséria do ser humano. Em seguida, outros autores são interrogados sobre a antropologia, de acordo com sua importância e influência em sua época. Assim são vistos pensadores cristãos da Idade Média através da filosofia, até chegar aos que declararam a batalha entre fé e razão, teologia e filosofia, Igreja e Estado. Naturalmente a modernidade contribui grandemente para que a antropologia buscada pelo autor se apresente mais ampla na medida em que são estudadas a crise da teologia, a psicologia que avança, o embate da religião com a psicanálise freudiana. Sem dúvida, temos nessa obra um panorama bastante amplo da trajetória da antropologia pensada em diversas épocas através de autores, culminando com o filósofo e teólogo jesuíta Leonel Franca. Na realidade, o autor nos leva a percorrer a história das relações de fé e pensamento, teologia e filosofia, Deus e os homens. Esta obra, sem dúvida, levará o leitor a um conhecimento mais profundo do Deus criador que constantemente busca sua criatura, o homem, para torná-lo, cada vez mais, semelhante a Ele.

174 ReVISTA de Cultura TeOlógica - v. 19 - N. 73 - JAN/MAR 2011 